\title{
8
}
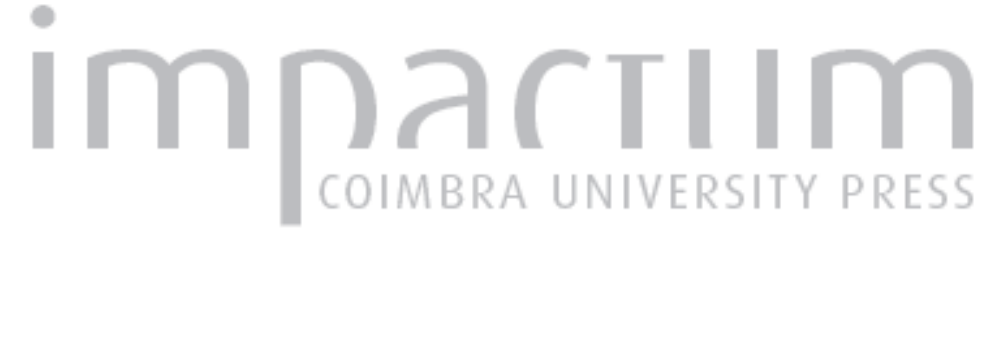

\section{Sade's delectatio morosa and the erotic sovereignty}

Autor(es): $\quad$ Pires, Edmundo Balsemão

Publicado por: Faculdade de Letras da Universidade de Coimbra, Instituto de Estudos Filosóficos

URL persistente:

URI:http://hdl.handle.net/10316.2/33384

DOI:

DOI:http://dx.doi.org/10.14195/0872-0851_34_5

Accessed : $\quad$ 26-Apr-2023 14:59:39

A navegação consulta e descarregamento dos títulos inseridos nas Bibliotecas Digitais UC Digitalis, UC Pombalina e UC Impactum, pressupõem a aceitação plena e sem reservas dos Termos e Condições de Uso destas Bibliotecas Digitais, disponíveis em https://digitalis.uc.pt/pt-pt/termos.

Conforme exposto nos referidos Termos e Condições de Uso, o descarregamento de títulos de acesso restrito requer uma licença válida de autorização devendo o utilizador aceder ao(s) documento(s) a partir de um endereço de IP da instituição detentora da supramencionada licença.

Ao utilizador é apenas permitido o descarregamento para uso pessoal, pelo que o emprego do(s) título(s) descarregado(s) para outro fim, designadamente comercial, carece de autorização do respetivo autor ou editor da obra.

Na medida em que todas as obras da UC Digitalis se encontram protegidas pelo Código do Direito de Autor e Direitos Conexos e demais legislação aplicável, toda a cópia, parcial ou total, deste documento, nos casos em que é legalmente admitida, deverá conter ou fazer-se acompanhar por este aviso.

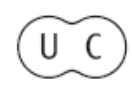




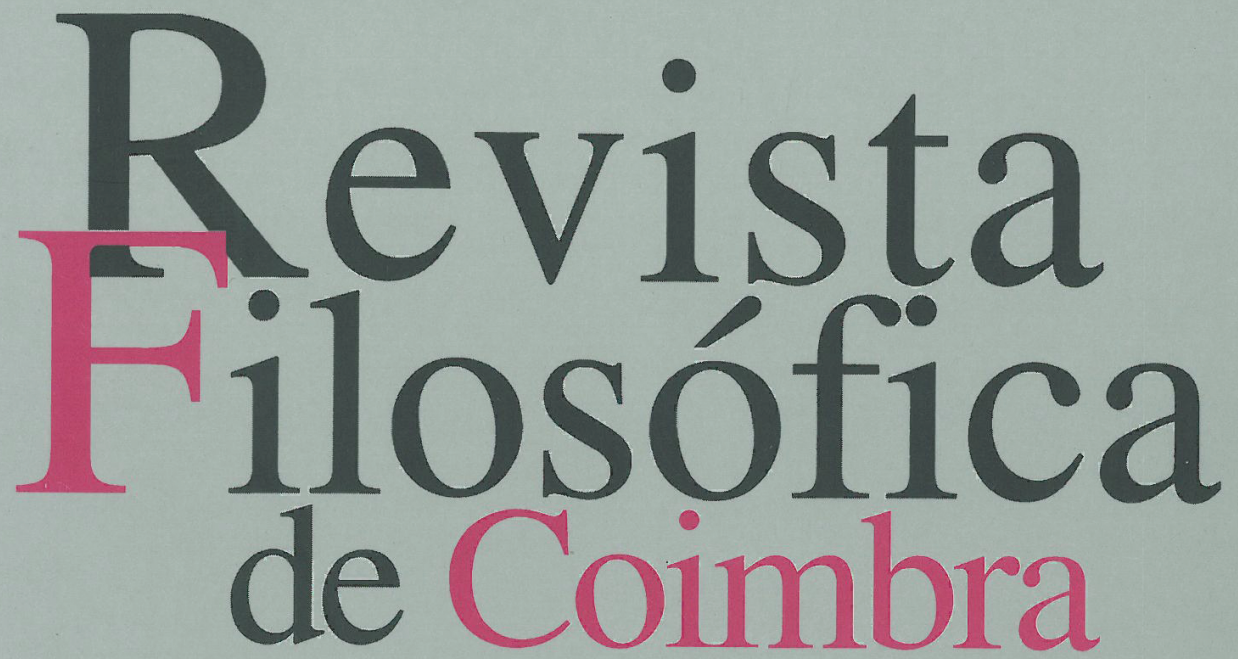

vol.17 | n.34 | 2008

José Reis

Manuel Moreira da Silva Helder Gomes

Filipe P. S. M. Menezes Edmundo Balsemão Maria João Silveirinha Luís António Umbelino Cláudio Alexandre S. Carvalho Armindo dos Santos Ana Isabel Boura Regina Queiroz Dulce Morgado Neves 


\title{
SADE'S DELECTATIO MOROSA AND THE EROTIC SOVEREIGNTY*
}

\section{EDMUNDO BALSEMÃO PIRES}

(Instituto de Estudos Filosóficos - Faculdade de Letras - Universidade de Coimbra)

\begin{abstract}
Sade's writings are a good example of the crisis of some corollaries of the XVIII century mechanicist interpretative model of human nature, for instance the thesis of the identity of the pursue of happiness and the self-conservation of its own individual nature, both responding to inclinations of the universal movement in nature.

With this presentation I would like to depict the complex interplay of individuality and eroticism in the epoch of the crisis of the modern mechanicist thinking. I'll take for scrutiny the case of Sade's writings.

In a variety of forms going from Literature to Art, Medicine and Philosophy modern society reveals worries about the coordination between choices of sources of pleasure, the self-observation of the subject, the social acceptability of some kinds of intimacy and interaction, the notion of moral personality and the "universal movement" as eternal cause of actions, including human actions, emotions and passions.

In French XVIII century literary culture a major part of these themes was articulated with the notions of movement, inner movement, sensation, conservation of the self, the parallelism between l' homme physique et l'homme moral through the passions or the notion of interest for example by de La Mettrie, Helvetius or D' Holbach, granting continuity to aspects of the XVII century mechanicist perspectives, and asserting a monistic, reductionist, image of the universal movement ruled by the laws of attraction, repulsion or inertia.
\end{abstract}

\footnotetext{
* This presentation is a partial development of the research project "Individuation of modern and contemporary Society " F. C. T. - L. I. F. - "Linguagem, Interpretação e Filosofia". This text is a continuation of the initial version presented at the International Meeting Normative Discourses on Family and Gender, Coimbra, 23 June 2008.
} 
The prestige of the scientific mentality brought the conditions for a generalized use of nature and movement as condensed formulas to abridge the complexity of the contingent connections linking bodily desire, self-perception and moral communication. The concepts of movement and nature were mobilized to recognize the contingent linkage of these areas. Saving aspects of the XVII century discussion of the value of "l' amour propre" (ex: La Rochefoucauld and Pascal) such themes as pursue of happiness, self-conservation or the protection of interests in civil society were the psychological and social main themes to make known the consequences of the universal movement in human life and in society.

The French expression "Le Système de la Nature" was a symbolic label of the belief in the conformity of all the realms submitted to the same universal movement. Sade was an heir of this general conception, but a disastrous inheritor for its survival.

By Sade one finds one of the most acute revelations of the difficulties in the conception of such universal conformity. A critical moment in the history of the harmonist, mechanical, image of human nature comes up, even if Sade continues the basic heritage of the ideology of "Le Système de la Nature".

Additionally, I'm going to emphasize, very briefly, how Sade accomplishes a relative separation between "le physique" and "le morale" showing how "nature" and "movement" are cruel and can be turned against pleasure and the self-conservation of the self. Such separation entails complexity and not reductionism. Accordingly, Sade is an author responsible for the imagination of a new sort of individuation of the human subject which is multilinear and not expressive and unilinear. Henceforth, the connections between the realms, "le physique" and "le moral", should be observed in individual events as self-referent results of the divergent domains, in contingency or, to use a heavy, serious term, in flesh.

Un fou! Le Marquis de Sade! Mais ce serait ôter à la folie ce quelque chose de sacré que lui ont accordé tous les peuples, ce serait faire de la plus grande maladie de l'homme, un crime.

Jules Janin $(1834)^{1}$

\section{1. "Sade" in the History of "Perversion"}

Since early, natural law doctrines, including Plato's conception in the third book of the Laws (689 d e ss.), insisted on the opposition between the "natural" and the "unnatural" to make sense of what should be approved and what should be morally condemned in human actions.

${ }^{1}$ J. Janin, Le Marquis de Sade, Paris, 1834, p. 46. 
Meaningful modern and contemporary ideas on "perversion" came from this prestigious historical background. Contradicting the unquestionable concept of nature the distinction "natural" vs. "unnatural" is a construction that demands descriptions of the "nature" on one side and the "unnatural" on the other side. The mutual exclusion of both sides also depends on descriptions and it is not "given".

An aspect of the history of these descriptions is the modern history of the concept of perversion.

Some centuries after the platonic doctrine and its Christian adaptation the same opposition between "natural" and "unnatural" came back in the public declarations and documents of the Catholic Church concerning issues going from contraception and birth control, abortion, in vitro fertilization and Clinical Assisted Reproduction, cloning techniques and other controversial themes.

The "natural"/"unnatural" dichotomy became decisive in what regards sexual behavioural discipline and especially in the generation of semantic equivalents to the initial moral difference between the acceptable and the forbidden or the avoidable. A large domain of sexual behavioural orientations and practical tendencies enter the field of the "abnormal".

If Sade's system of nature in La Nouvelle Justine or in La Philosophie dans le Boudoir doesn't work with the negative polarities ("natural" vs. "unnatural") starting instead from a monistic theory of nature's universal movement, the concept of nature is also established on a normative ground, even with contradictory consequences.

In 1958, by occasion of a presentation in the Collège de Philosophie G. Canguilhem established the triple genealogy of some physic-psycho-pathological theories on mental disease in the theoretical, clinical and organizational (asylums) fields (G. Canguilhem, 1958).

From some results of this complex genealogy we are able to appreciate how XVII century French philosophical doctrines on the "mind-body" problem, on the connection between bodily movements and mental representations and on "Physiology" were influential in the normative orientations towards insanity or "alienation" in the XVIII century and the correspondent measures concerning the creation of asylums during the late Ancien Régime and also in the revolutionary and Napoleonic periods.

Immediately after J. Colombier and Fr. Doublet's «Instruction sur la manière de gouverner les Insensés» (1785) that divided the categories of mental disease and the asylum population in the groups of the frenetic, maniac, melancholic and imbecile, the notion of "mental alienation" didn't include the special group of the "sexual perverted". 
This epoch tends to comprise under the same loose category of "insanity" the affections of the "moral sense". Insanity, "alienation mentale" or "manie" are terms used by Ph. Pinel to describe behavior or other symptoms subordinated to the general "principles of moral treatment" 2 .

Sade's Charenton imprisoning was justified by this belief in some similarity between the moral, the sexual and the mental and in the force of "moral treatment" regarding all sorts of deviations, moral or mental disturbances.

A great variety of philosophical and medical doctrines on the subject of physiological underpinnings of self-knowledge will be decisive for the normative horizon of $\mathrm{Ph}$. Pinel and the generation of physicians under his influence or proximity. Antoine Athanase Royer-Collard was not an exception. But this physician, who occupied the first chair for "mental medicine" in the University of Paris, was also during a particular period the director of the Charenton asylum, where Sade was imprisoned.

From the first encounter between "Sade" and what he represented for the psychiatric discourse we have a written record in the incoherent depiction of Antoine A. Royer-Collard to the Ministry of Police: "the man is not mad. His only madness is that of vice.... Finally, it is rumoured that he is living in the asylum with a woman (Mme. Quesnet, who has on her own initiative moved into Charenton to be with Sade) whom he passes off as his daughter"3.

The difficulty in the establishing of an operative distinction line between the moral, the bodily (or the physiological) and the mental with regard to sexual behavior is at the edge of the investigation on the nature of sexual perversions, later on the XIX century. This led to paradoxes such as Royer-Collard's: one says that Sade is not mad even if one suspects that he should be treated for his vicious tendencies.

$2 \mathrm{Ph}$. Pinel, Traité médico-philosophique sur l'aliénation mentale, Paris, 1809.

3 (...) Il existe à Charenton un homme que son audacieuse immoralité a malheureusement rendu trop célèbre, et dont la présence dans cet hospice entraîne les inconvénients les plus graves: je veux parler de l'auteur de l'infâme roman de Justine. Cet homme n'est pas aliéné. Son délire est celui du vice, et ce n'est point dans une maison consacrée au traitement médical de l'aliénation que cette espèce de délire peut être réprimée. Il faut que l'individu que en est atteint soit soumis à la séquestration la plus sévère, soit pour mettre les autres à l'abri de ses fureurs, soir pour l'isoler lui-même de tous les objets qui pourraient exalter ou entretenir sa hideuse passion. Il n'est pas nécessaire, je pense, de faire sentir à Votre Excellence le scandale d'une pareille existence et de lui représenter les dangers de toute espèce qui y sont attachés (Antoine-Athanase Royer-Collard au Ministre de la Police Générale cit. in G. Lely, Vie du Marquis de Sade, Paris, 1965, pp. 640-641). 
Is "Sade" a juridical-criminal theme ("violation", "rape", "sexual harassment"?) a moral topic for discussion, condemnation or approval ("vice"?), a case of mental disease ("perversion"?), or is "Sade", above all, a sign in a literary oeuvre, or all these possibilities together?

These questions were especially relevant due to the political exigencies of the epoch at the end of the Ancien Régime, characterized by a generalized naturalization and rationalization of the observation of nature associated with the lost of the old social meaning of the religious confession.

Modern society emphasized the distinction between "natural" and "unnatural" to deal with this kind of coordination problems between communication, self-consciousness and the self-construction of sexuality.

One of the main difficulties with this distinction lies on its own structure. One is not able to talk directly from the "nature". "Nature" is mute. One needs to establish what nature is and what shall count as "natural". This is the reason why the distinction "natural" / "unnatural" needs a special observation, a science (medical science) for the positive establishment of the "natural" facts of human sexuality, and the institutionalization of the conditions of observation of nature and its deviations (the asylum and the hospital, but also the prison for common crimes). It is not casual that some of the most relevant texts for the classification of sexual perversions were dictated by the needs of the modern criminology.

R. von Krafft-Ebing's Psychopathia Sexualis (1886) was vital in the scientific fixation of the current idea of the reproduction of the species as the main aspect to consider in order to separate the "natural" and the "unnatural", the "normal" and the "abnormal" in human sexuality and in sexuality generally speaking and it was also decisive in the generalization of the semantic of "sadism"4.

In his work R. von Krafft-Ebing used the distinction natural /unnatural to organize an entire typology of sexual pathologies. Perversions make a central part in this typology and "sadism" has its place here.

If communication about nature is not necessarily proved or directly articulated with perception of nature, but remains autonomous, this entails the difficulty of the encoding of perception into communication and conversely. I'm referring here to a difficulty, because it is never possible to completely encode perception of nature into communication on nature or conversely.

${ }^{4}$ See. R. von Krafft-Ebing, Psychopatia Sexualis, (1886) reed. München, 1997, pp. 47 and 69. 
R. von Krafft-Ebing's Psychopathia Sexualis is an example of an encoding choice concerning the alternative. The book reveals the importance of the establishment of communicative conditions for the communication on natural facts of human sexuality by sentences concerning the perception of nature and natural finality of internal motions, continuing in the semantic tradition of the German medical concept of Trieb.

R. von Krafft-Ebing established the role of the medical studies in the determination of a useful concept of sexuality as the necessary natural ground for the comprehension of the laws concerning the "Kehrseite des Lebens, menschliche Schwäche und Armseligkeit"5, that will guide the criminologist or the policy-maker.

Communication on natural motions of the body is thus guaranteed by a special class of scientific discourse, the psychopathological, encoding discourse and communication into "direct" perception of nature, creating the illusion of a self-presentation of "nature by itself".

Summarizing some ideas from Psychopathia Sexualis we can articulate five main subjects.

1. The starting point of the Psychology of Sexual Life is the biological reproduction of Human Beings connected with a natural, internal impetus (Naturtrieb) that demands fulfilment; 2. The satisfaction of the natural impetus engages bodily and spiritual characteristics of the Human Beings and it is not limited to the physical, organic realm and such characters can be transmitted hereditarily; 3. Human Beings have the same natural impetus as the animals, but additionally they have abilities for spiritual activities such as the capacity for the creation of an "Ethical World" and a "World of Beauty"; 4. The natural sexual impetus is also a social, gregarious force that ties people together and it is the ground for such social achievements as family, religion, ethical life and aesthetical interest; 5. The definition of perversion entails the expressions of the sexual drive that don't contribute to the accomplishment of the sexual reproduction coinciding with nature's internal finality.

Before introducing "sadism" Krafft-Ebing referred the difference between "Perversion" and "Perversität". "Perversion" defines a disease and has its place in the Psychiatric nosology. "Perversität" means "vice" (Laster). The distinction of these two types requires the observation of the whole of the character but also the analysis of the causes of the perverted actions. However, the author is aware of the difficult definition

${ }^{5}$ R. Krafft-Ebing, op. cit., p. V. 
of the mental aspect of the disease abstracting from moral connotations concerning "vice".

Psychopathia Sexualis conceived three main types of "sexual neurosis": peripheral neurosis, spinal neurosis and cerebral conditioned neurosis. In this last type is included "sadism" as a particular case of cerebral conditioned neurosis or what, in a particular vocabulary, the author calls "paraesthesis" (Parästhesie). The formal definition of "Parästhesie" states: Perversion des Geschlechtstriebs, $d$. h. Erregbarkeit des Sexuallebens durch inadäquate Reizé.

The reason for the inclusion of "sadism" among other "sexual neurosis" is justified by the fact that sadism is a disease concerning the sexual excitability. On the other side, it is not sign of a regional or peripheral deficiency, but implies the whole of the organisation of pleasure and a wrong synthesis between external or inner sources of sexual excitement and pleasure. In sadistic activities pleasure arises as a consequence of an association between erotic motion and the psychic representation of cruelty and domination: Verbindung von aktiver Grausamkeit und Gewaltätigkeit mit Wollust ${ }^{7}$.

If we take into consideration the combination of paraesthesis and hiperaesthesis it follows two possible types of perversions in the orientation of the sexual drive: sadism and masochism. Both sadism and masochism constitute such deviations of the natural Sexualtrieb that imply always an orientation towards the other, a Mitmensch or an animal.

The reports R. Krafft-Ebing made from his clinical observations show how so-called sadism normally engages two people (in particular cases more) in sexual contact revealing in their behaviour some repetitive episodes such as inflicting pain in the other, pleasure in pain or pleasure in transgression. In extreme cases one can also find the pleasure in death. This has been shown in battlefields or in some historical illustrations of pleasure in death, for instance Gilles de Rais historical murder cases.

${ }^{6}$ Idem, Ibidem, p. 47.

7 The approximation of some aspects of Sade's "life and work" and revolutionary terrorism led the sexologist Iwan Bloch to the definition: Sadism is the purposively sought or accidentally presented connection of sexual excitation and pleasure with the actual or also only symbolic (ideal or illusory) occurrences of strange and terrifying events, destructive processes and actions, which threaten or destroy life, health and property of men or other living beings whereby the person receiving sexual pleasure from such events may be the originator or spectator, voluntary or involuntary (Iwan Bloch, Marquis de Sade: His Life and Work (1899) (transl.), The Minerva Group Inc., 2002., p. 131). 
A very important characteristic R. Krafft-Ebing points out is the "sexual hyperaesthesia". This occurs like a general physiological excitement and mental fever but the consequence is the inversion of the situation, the author calls "psychic impotence". The concentration of mind in the perverted actions devours a lot of psychic energy, especially in the imaginary pursuit of the inner drive, and produces extenuation.

Thus, one can understand why for Sade a key part of the meaning of sexual appetite is described in the language of energy and forces.

Another aspect links "sadism" to gender differences. According to R. Krafft-Ebing sadism is more frequent among men than women. The justification for this conclusion is the abnormal development of the characteristics of the masculine desire, which is evident in sadism, such as the lust in the submission other people. The orientation towards domination by means of the sexual intercourse would be typically masculine. However, the same author depicts two cases of the so-called "Sadismus des Weibes".

In the History of Psychopathology one finds other examples of the same idea of a reduction of perversion to "anti-natural" behaviour that doesn't include only sadism. J.-M. Charcot and V. Magnan well known brochure on the "Inversion of Genital Orientation and other sexual Perversions" (1883) consecrates the current notion according to which a sexual perversion is a degeneration occurring in the normal flux of an inner motion or impetus ${ }^{8}$.

Both authors conclude that some perversions can lead to a complete degeneration of personality, conducing to "la perversion morale" or "folie". Again, the limit between insanity and moral deviation is not clear; there is not a definitive barrier between the physiological perversion and vice or moral perversion. According to the observations of R. Krafft-Ebing and J.-M. Charcot one aspect is mirrored on the other, "le physique" on "le morale".

Later, the concept of perversion took place within a genetic, developmental narrative in the work of the physician Albert Moll, especially in his book on the Sexual Life of the Child (1908), where the author tries to identify some stages along the child's evolution on the way to the adult age.

After an initial stage he calls "neutral stage", using the terminology of Max Dessoir, the child comes to a new phase, the "undifferentiated stage". During this one the child experiences certain affections of sexual nature that cannot be completely described by means of relations towards

\footnotetext{
${ }^{8}$ See. J.-M. Charcot / V. Magnan, Inversion du Sens Génital et autres perversions sexuelles, Paris, 1883 (reed., Paris, 1987).
} 
objects accompanied by genital excitement, which are forgotten in the adult period of the life. All sorts of "perverse sentiments" occur in this stage, including "sadism" . According to this genetic perspective, the idea of an inborn perversity is limited if not false and chance plays also an important role. It is easy to establish the continuity from A. Moll's ideas to Freud.

But along these genetic explanations one shall recognize the continuity of the ancient idea, modified by the mechanicist bias, regarding the unity of nature and human nature, natural causation of motion and of some intentional actions and the external signs of the accordance of the individuated beings with nature's internal and external rhythm.

What is at stake in the modern history of the concept of perversity is the normative direction towards an orthosensory body, a body that continues nature's motions and inclinations. However, the simplicity of this description implies a strong reduction of the complex structure of the representation of what is meant by such orthosensory body.

Every mature human being shall arrive at some results concerning her (his) quest for the adequate form of his (her) own sensorial organization and along this quest every human being have to solve a great variety of enigmas pertaining to the coordination between emotional conditions and states, internal self-observation, and ego idealization, and social conditions for communication about oneself. But, this perspective comes from the conviction that there is no pre-established harmony across all the aspects of the experience of the self, justified by nature's universal motion, for instance ${ }^{10}$.

The orthosensory body results from the complex arrangements one need to engender in order to communicate about internal experiences with emotional content, within the general code difference allowed/not-allowed. Orthosensory bodies are coordination implements coupled with perception, emotional and communicative forms. But there is no such thing in nature. As a form made of forms it results from history and from constructions.

${ }^{9}$ A. Moll, The Sexual Life of the Child, (trad., New York, 1912, reed. 2000), pp. 234-236 and 262.

10 This conclusion appears to be opposed to the ideal of happiness as accomplishment of the human life in accordance with nature in the writings of the ancient Epicurism, as read by the XVIII century mechanicist authors from de La Mettrie to Helvetius and d' Holbach. See. de La Mettrie, L'Homme Machine, suivi de l'Art de Jouir, Paris, 1921, pp. 103-104. 
The Modern conception of perversity expresses the coordination implied in the self-generation of the orthosensory body as if the difficulties of this coordination were solved. Accordingly, "perversion" takes place as the opposite model of the orthosensory body.

Typological XIX century theories on perversity make use of an identity concept for the person and for the relation between internal states and personal identity. Because this relation is changeable an essential problem arises: how to deal with the moveable, energetic, production of internal emotional meaning on one side, and stasis, identity and fixation of meaning on the other side. Phenomena of repetition, compulsory repetition, for instance, were analytic predilections, because repetition invokes a rule in the formation of stasis, and rules are most probably based on beliefs in permanence or identity.

Around "perversion" XIX century psychopathological typologies described the stasis of motion and desire and the objects responsible for some particular stasis as "abnormal" formations. A special case of perversity is sexual perversity. From the typological descriptive habits of XIX century one easily specifies categories of sexual perversion: bestiality, necrophilia, homosexual acts, anal sex and oral sex, fetishism, masochism and sadism. The criteria for the grouping of the categories of sexual perversion were based on two alignments of the sexual internal motion which were responsible for its provisional stasis: the finality or end of the motion and the objects fixing the motion.

From this double perspective one is easily led to the identification of the channels and objects for the discharge of internal motion, under predictable pressure, or the finality of the motion. But in the case of sexual perversion these two kinds of stasis were negatively identified. In these cases stasis is "bad" stasis, distortion, orientation against nature's ends.

Let me be clear by saying that for this historical, typological, description of perversions the decisive is the modulation of the internal psychic motion by some stasis formations, which are depicted as "abnormal".

Around the formation of the types of perversion the psychopathology of the XIX century never seriously discussed the vitalistic legacy of the XVIII century German concept of Bildungstrieb, from Blumenbach inspiring concept to Goethe's ideas on natural morphogenesis.

Unnatural moves are to be waited as a consequence of special conditions occurring in the decay of motion. Perversions and especially sexual perversions are singular cases across the corridor from the beginning of motion to its ending.

Thus, the direction of the decaying of motion is the first aspect to be equated in the way towards the identification of possible abnormalities. 
Repetition of the same deviant decaying process is a second stage. And the discovery of a rule for the repetition of a "perverted" decaying of motion will be the confirmation of perversion, as such.

But one should understand better what makes this process really "abnormal" when "perverse". The link is well established: "abnormal" implies unusual forms of decaying of motion, or against nature, found in habits.

The medical discourse on perversions also makes use of the concept of "degeneration" which knew also political and racial applications.

The close relation of "abnormal" with perversion and "contrary to nature" is the ordinary formula to surpass the difficulties with the definition of the "abnormal" decaying of motion from within the motion itself.

Thus, one needs the fiction of a nature and the representation of the regular decaying of motion in nature as the measure for the abnormal. From the construction of the regular decaying of motion in the whole of nature one is able to capture the finality of all particular motions in finite creatures as well as in men, because the deciphering scheme for the particular finalities is some agreement with the whole. Accordingly, orthosensory human bodies are "organizations" that replicate the image of this agreement with the whole in the inner projection of the inner motions across the different parts.

But, for the establishing of the meaning of this agreement observation in the sense of perception, alone, will not be enough. Additionally, one needs communication about nature. By communication I understand meaning connections which do not depend exclusively on perception and consciousness (thought), but have its own grounds on social interaction, system observation of society, semantics and discourses more or less institutionalized.

Orthosensory bodies are described according to their difference towards perverted bodies always with the help of this encoding.

Freud in his discussion of a primitive impulse for death clearly noticed a tendency in the psychic system towards actions that don't contribute to the self-preservation of the subject. This same tendency is responsible for destruction, violence, aggression, cruelty and for such actions that develop outside the margins of the "principle of reality", challenging the coordination abilities in order to keep aligned the psychic representation, the internal motions, the external objects or finalities and communicative expectations. Sadism and sado-masochism would be easily integrated in the general frame of "destructive forms of sex". But, precisely, a major theme is the explanation of this psychic disconnection regarding the habitual ways of self-preservation. 
Aware of the need for a new understanding of the economic role of perversions in psychic life, Robert J. Stoller in his book on Perversion dissected the situation of the contemporary theoretical conception of "perversions" along two major tendencies" 11 .

A first development comes from the recent scientific research and data leading to the idea of the inappropriateness of the traditional concept of "perversion" to establish rigorous categories for psychiatric identification of mental illness, due to its moral connotations and the inaccurateness of the traditional concept of mental illness associated to the investigation of so-called "deviant behaviour".

A second inclination of thinking starts from the recognition of the importance of moral beliefs on adequate behaviour in order to separate what is socially and morally allowable from what deserves moral blame, insisting on the need for "old fashioned" concepts, such as perversion, in order to identify the dividing wall.

If we acknowledge the well-founded of the scientific conclusion on the weak character of traditional theories and types of perverted behaviour, especially in the case of sexual behaviour, we are in a difficult situation to justify moral beliefs concerning so called "perversions".

The dividing line between convenient moral behaviour and abnormal conduct is not grounded on positive beliefs of the scientific community, but on the other side the scientific convictions can't lead to moral rules or moral guidance.

The contemporary evolution of psychoanalysis and psychiatric typologies shows a tendency to the replacement of the uncertain word "perversion" with expressions such as "paraphilia"12.

Branches of scientific knowledge concerning psychopathology were indeed initially conceived from the perspective of the natural / unnatural generative opposition. The making of the idea of perversion was also a consequence of the canonical use of the concept of nature regarding social habits and conformity to rules.

In the end of the sixties French Psycho-analysis inspired by J. Lacan's work tried a different way in the approach to Perversion, showing how in the constitution of some desire formations is at stake a complex combination of imaginary elements aggregated to inter-subjective recognition. In the understanding of desire, the quasi biological language

${ }^{11}$ See. Robert J. Stoller, La Perversion. Forme Érotique de la Haine, (trad.), Paris, 2000 (reed. 2007).

12 See. Alan G. Soble, "Paraphilia and Distress in DSM-IV"in Jennifer Radden, The Philosophy of Psychiatry, Oxford, 2004, pp. 54-63; Alan Soble, The Philosophy of Sex and Love, St. Paul, Minnesota, 1998, Part I, chap. 2 pp. 27-43. 
of neediness should be abandoned and theory should focus on the knot of imaginary and communicative elements. This aspect of the new orientation is especially relevant in the case of the analysis of the "perverse couple" (Cf. J. Clavreul) and the complex combination of communicative and imaginary elements in the constitution of desire displayed by this model ${ }^{13}$.

Recently, Robert J. Stoller combining gender analysis and psychopathology proposed an explanation for the development of "deviant" behaviour namely in the field of sexual behaviour, so-called "perversions", using a dynamic defensive approach and calling into consideration the idea of a gendered "identity", "masculinity" and / or "femininity", in the constitution of personality. One regrets R. Stoller didn't pay full attention to the special case of so-called "sadistic" personality.

Perversion meant for him a defensive response to what is felt as a menace to the integrity of the gendered identity of the subject and, with this meaning, perversion has a decisive connection to anxiety and to the family unit where the infans become a person according to a dynamic process of individuation.

Revising the freudian conception concerning the initial heterosexual desire of the little boy regarding his mother, Robert Stoller, sustaining some Jungian intuitions, concludes, differently, from his clinical experience and theoretical conception: boy or girl are initially symbiotically connected with the mother, a situation referred as "fusion with the other", and they shall accomplish a continuous process of individuation in order to become "masculine" or "feminine" 14 . In the case of the boy one notices a period of crucial resolution of the symbiotic relation with the mother, accompanied with the so-called "anxiety concerning symbiosis" 15 , a fear of reintegration in the feminine body of the mother. What an adult calls "feminine" and "masculine" are results of a complex psychic and bodily experience of selfawareness, in both boys and girls, which very acutely Robert Stoller identifies by the term "individuation".

According to him and to core trends in the psycho-analytic tradition perversion and perverted behaviour occur within a complex frame entailing sexuality, psychological fixation on partial objects, phantasms and the degree of the achievement of individuation and gender individuation, particularly.

${ }^{13}$ See. Aulagnier-Spairani / J. Clavreul, / F. Perrier / G. Rosolato / J.-P. Valabrega, Le Désir et la Perversion, Paris, 1967.

${ }^{14}$ Robert J. Stoller, La Perversion. Forme Érotique de la Haine,(trad.), Paris, 2000 (reed. 2007), p. 176.

15 Idem, Ibidem, p. 191. 
But individuation as a process depicts the formation of psyche from the initial stage of the belonging to the mother, which characterizes both the feminine and the masculine human beings. We have to envisage here two extremities of a movement from symbiosis to separation, the corresponding psychological reactions and the eventuality of regressions. Biographical time is organized along and as the consequence of these tensions. The individual effort towards separation implies a memory of proto-subjective experiences but implying always the psychic elaboration of the mourning of the mother's body. The temporal and imaginary structure of melancholy appears against this background.

The transgression of the history of "perversion" within this new analytical frame ${ }^{16}$ requires a new light on the meaning of "sadism" and a renewal of interest in the examination of Sade's work. The mechanicist idea of natural motion (external or internal) and mechanical causation can't satisfactorily describe the complexity of this new understanding which entails the autonomy of the physical, the psychic and the communicative, and contingent links between them across the process of individuation. The association between Sadism and "death impulse" may explain why in the cases of sadism we have to envisage the disconnection of the psychic system from the whole of "le système de la nature" based on self-preservation. But we have to ask, also, if this disconnection is not structural and not a fail in a more natural, essential, alignment of "le physique" and "le morale".

\section{A Practical Wisdom of the Negative}

\subsection{Wisdom through Flesh}

Modern Society systematized a complex semantic web of terminology, ideologies, general ideas and topics, a great variety of texts and also

${ }^{16}$ Further reading: Thomas Nagel, "Sexual Perversion" inn The Journal of Philosophy, vol. 66, no 1 (Jan., 16 1969), pp. 5-17; Robert Gray, "Sex and Sexual Perversion" in The Journal of Philosophy, vol. 75, nº 4 (Apr., 1978), pp. 189-199; Ivan Crozier, "Philosophy in the English Boudoir: Havelock Ellis, Love and Pain, and Sexologic Discourses on Algophilia" in Journal of the History of Sexuality vol. 13, no 3 (Jul. 2004), pp. 275-305; Anthony Parfitt, "Impasse and the Interpretation of Perversion" in Journal of Child Psychoterapy vol. 32, $n^{o} 1$ (2006), pp. 49-65; O. Sternbach, "Aggression, the Death Drive and the Problem of Sadomasochism: A reinterpretation of Freud's Second Drive Theory" in Psychoanalytic Review, 93 (6), (Dec. 2006), pp. 857-881. 
literary genres to deal with the contingent connection between nature, consciousness and communication in society ${ }^{17}$.

The local and partial characteristics and features of this semantic web are varied but its general meaning consists on this: to give answers to the need for regularities, order, simplicity in a domain essentially fluid and contingent and impossible to characterize by intentionality.

Developing the intellectual legacy of Maupertuis the mechanicist French writings of the second half of the XVIII century, beginning with the Traité de Dynamique (1743) by D'Alembert or L'Homme Machine (1748) by de La Mettrie, are mostly concerned with the idea of a unifying doctrine of movement able to explain not only the physical causality, time and measure of time, mass and force, types of movement according to surfaces, collision and impact, gravity, elasticity, but also those aspects pertaining to life and the human being.

The French mechanicist culture evolves to a metaphysical explanation of the real, physical, biological and anthropological, and the problem of the physical-psychic causality is always nearby. The book attributed to Abbé Macy under the title Traité de l'Âme des Bêtes (1737) testifies this metaphysical orientation ${ }^{18}$. However, according to my view the theoretical problem of the physical-psychic causality, and its limits, was never seriously treated in the intellectual context of the XVIII century, except in the case of the genetic explanation of the sensation formation ${ }^{19}$.

The mechanicist culture believes in the power of a unifying explanation and if the concept of force seems to be able to describe physical causality, to a certain degree, it must be converted in order to represent connections in the biological and anthropological areas. Finally,

${ }^{17}$ An interesting historical examination of the interplay between the physical, the psychic and the communicative concerning the passions and sexuality: G. L. Mosse, "Nationalism and Respectability: Normal and Abnormal Sexuality in the XIX Century" in Journal of Contemporary History vol. $17 n^{\circ} 2$ (Apr., 1982), pp. 221-246.

18 See. Traité de l'Âme des Bêtes, avec des réflexions physiques et morales, par M. l'abbé M. [Macy], Paris : P. G. Le Mercier, 1737, especially Article III, Le Corps de l'Homme aussi bien que celui de la Bête sont de pures machines, pp. 27-28 and Légere description du méchanisme de l'Homme, pp. 28-32.

19 Condillac's mental experiment of the statue is very convenient for the purpose of a general depiction of the influence of the physical in the psychic, also explaining how the sensation is produced by mediation of the movement, but the problem of the preservation of the psychic representations, impressions and ideas, by the internal, selfsufficient reference of the psychic to itself was left open, because this question entails the supposition of the autonomy of the "psychic" with regard to the "physic". See. E. B. deCondillac, Traité des Sensations (1754) Paris, 1788. 
from the anthropological field one must be able to infer moral, social and political consequences, according to the same mechanistic explanation. The work of Helvetius and d' Holbach are good illustrations of such penchant.

Are nature, consciousness and communication ultimately ruled by the intentionality of God and the divine rules are the rules of the internal consistency of these three realms? Nature and universal movement are other signifiers to express this immanent, but intentional, power? Or nature, consciousness and communication are never in an encompassing rhythm and the connection of body, representations of needs and desires and communication is itself a product of contingency referred to a complex, non-reducible, non-intentional, process of individuation, whose rhythm is chaotic?

Moral rules, juridical precepts, expectations born in interaction and crystallized on symbols are effective in the establishing of what nature "is" or nature "exceeds" communication also showing, by the description of such excess, that there is nothing stable directly facing us under the blueprint of "nature"?

Sade's work is at the crossroad of the majority of these questions. He represents one of the best symptoms of the crisis of the old sovereignty concept in the provisional essay to integrate nature, consciousness and communication according to an intentional plan. His work shows how the different realms the mechanicist view incorporated under the same idea of the universal movement are relatively opaque, impenetrable, and what one calls "nature" is perhaps just a sign, or brute force exerting a blind pressure towards an impossible expression of its own.

The libertine literature, before and after Sade, continues a large sequence of literary and philosophical writings devoted to the understanding of the dictum "live in accordance to nature" as the rule of happiness ${ }^{20}$, but not all the aspects of the libertine heritage are in accordance with the moral consequences of late XVIII century mechanicist French culture.

${ }^{20}$ One of the best testimonials for the description of the cultivated people under the label "libertines" in the XVII century is the work of their enemy, Père F. Garasse. See.F. Garasse, La doctrine curieuse des beaux esprits de ce temps ou prétendus tels contenant plusieurs maximes pernicieuses à la religion, à l'Estat, aux bonnes moeurs, combattue et renversée par le P. François Garassus, Paris, S. Chappelet, 1624. 
Recently, specialized literature ${ }^{21}$ emphasized the importance of ancient sources from the Skeptics, Epicurus passing through Lucretius through M. Montaigne and P. Charron to Gassendi, the author of the Theofrastus Redivivus and to the XVII century "Libertins Érudits" and "les écrits des esprits forts" in the making of a very influent "radical Enlightenment", where is to be found the place for the libertine literature and, later, Sade.

If we examine Sade's writings not from the perspective of pornography but from the point of view of the semantic and philosophic effects of the ancient concept of practical wisdom we see that he dealt with the particular question of the self-knowledge of the subject.

Sade's work shows very acutely how the platonic understanding of the divergence between bodily desire and rational knowledge distorts the very idea of a self-knowledge of an embodied subject.

According to Sade the embodied subject is the individual outcome of the impossible harmony between communication (particularly moral communication), the consciousness and nature or bodily desire, a multilinear outcome. Along Sade's literary route what is thoroughly at stake is the experimentation with the inner contradictory knot of the internal motions, desires, the self-knowledge of the individuated subject, communication with others and the impossibility to declare a homogenous and intentional interplay across these realms. In La Philosophie dans le Boudoir his theory on the artificial origin of laws, social habits, kinship ${ }^{22}$, religious beliefs ${ }^{23}$ and the State is not only based on the clandestine literature connected with the reception of the Contra Celsus and the book on the Three Impostures, but has relevance by itself regarding the statement of the thesis that nothing morally relevant is given by nature.

The notion of flesh is perhaps suitable to articulate the internal tension of the self-knowledge of the individuated, multilinear, subject across the non-coincident levels of the making of its own meaning, because there is no intentional harmony across such realms.

${ }^{21}$ See. J. Prévot, "Introduction” in J. Prévot / T. Bedouelle / E. Wolff (eds.), Libertins du XVIIe. Siècle, 2 vols., Paris, 1998-2004, vol. 1, pp. IX-LXXXVIII; F. Charles-Robert, Les Libertins érudits en France au XVIIe. Siècle, Paris, 1998; J. I. Israel, Radical Enlightenment. Philosophy and the Making of Modernity 1650-1750, Oxford, 2001.

${ }^{22}$ On this particular subject see Josué Harari and Hélène Pellegrin, "Exogamy and Incest: De Sade's Structures of Kinship" in $M L N$ vol. 88, $\mathrm{n}^{\circ} 6$ "Comparative Litterature" (Dec., 1973), pp. 1212-1237.

23 See Sade, «Français, encore un effort si vous voulez être Republicains», «Les Mœurs» in La Philosophie dans le Boudoir, Paris, 1972, pp. 210 and foll. 
Libertine writings and Sade's texts evidence an acute awareness concerning the non-linearity of the connections between the social and communicative conditions of the discourses on the desire, the psychic wakefulness turned to the desire and the bodily inscriptions of this distinction. This is a partial justification for Sade's deliberate use of the language of deviation, crime, punishment and for his own excitement with "pleasure in transgression" defining the practice of life of the libertine and his discovery of the other face of "nature".

What interests Sade is the flesh as animated body sacrificed to meaning. What he examines with no limits is the extension of this sacrifice, from the physiological conditions, toward the moral modalities of the extreme impure, dirty flesh or the virgin, chaste and clean.

The libertine discovery of the flesh will engage a serious experimentation with the limits of oneself and such discovery can't tolerate the subordination to moral discourse, political arrangements or laws. This is the reason for the frequent severe reproaches Sade directs against religion and moral principles: frequently these principles are limitations on the power to examine oneself lucidly with no excuses. But this noncompliance demands an approximation between the libertine and old forms of sovereignty and a dream of a detached life.

Also, the unity of the ego is now disputable. Even if one dismisses the metaphysical content of res cogitans it is possible to preserve some kind of unifying function in mental activity around a psychological ego. But, according to Sade this one is a theatrical side effect of the organization of the flesh. By Sade it is reduced to the function of an eye in the self-observation.

The libertine experimentation shows why the flesh can't be described as an uncomplicated stuff, but its proper definition refers to a sort of sacrifice, an internal subjective clash which has its cause in the crossreference of body, thought (representation) and communication. By crossreference I understand the contrary of an expressive, causal link, between body, consciousness and communication.

I understand a nexus by which the signifier of the bodily desire turns into an unworkable content of the communication or turns into the nonsynchronous, pale, non-vivid, past, decayed, conscious representation. This means a basic, irreducible, non-coincidence of the self inside itself. The sacrifice and the "ego" as a sacrificial effect accomplish in a series of ways the subordination of the deep motions to meaning. Sade aspired to describe the moments and details of these sacrificial subordinations. This was his literary dream.

This reveals a conflict that creatively forms the truth of the individual, markedly through stress and pressure and not peacefully. It is this 
condition that creates the need for wisdom, the need for a sadean practical wisdom.

It is important to notice that the predominant concept to recognize individuals was in the XVIII century the concept of what I called, in another essay, "expressive individuation". This means that the individual is a consequence of an expressive organization of meaning from the natural organism to social interaction. The origin of the expressive individuation is the belief on the sense of the Creation.

With the exception of $\mathrm{T}$. Hobbes the mechanicist culture of the seventeenth and eighteenth centuries continues the intellectual effort to keep the harmonism of the expressive individuation. Monsters, deviations, crimes, perverted creatures are exceptions in the right route of nature's self-expression.

On the contrary, the truth of Sade's libertine subject is not dependent on the victory of reason against wrong, unnatural, passions, establishing a sort of guiding role, but it is the truth of a passionate individual mirroring itself and its own exposure to the violent breadth of the flesh, traversed by thought (connections of thoughts, images, etc.) and communication.

But, this opens a new idea of human individuals and subjective individuation. Sade shows clearly that nature, movement, inner impetus, passions or tendencies, needs, are mute. Their unique idiom is pressure and stress. They express nothing. The domain of the expressive and communicative categories is always displaced from what we call "nature". The unity of "man" is only guaranteed by retrospection, by meaning retrospections concerning what rests as nature.

This reveals how Sade inspired a new concept of individuation, which I would call multilinear individuation in order to establish the difference from the expressive individuation which is unilinear.

On the concept of the multilinear individuation of the human subject lies also the temper of Sade's wisdom: it is not a wisdom that leads to serenity and peace of mind but to energy and to an extenuating concentration on oneself to be in accordance with the sleeplessness of the flesh.

What Sade accomplishes is the writing of the acts conducing to what the literary language can illustrate as the meaning of the flesh, but a meaning always in displacement along the history of its cross-references and along the history of the internal displacement of the self.

According to the classical heritage Sade's literary writing could be conceived as an impossible case of wisdom. But, textual references to Seneca and P. Charron ${ }^{24}$ in La Philosophie dans le Boudoir are good

${ }^{24}$ Idem, Ibidem, p. 218. 
examples of the value Sade conceded to the classical notion of wisdom especially in stoic versions.

The inconsistency lies on this: to have the virtues of a libertine sage one needs to live exposed, violently, risking the life and still maintaining the talent to record risks into a literary fresco, a power of the imagination.

Serenity is not the ultimate value, but concentration of mind, sleeplessness, a relative indifference toward what is not connected to the contingency of the flesh.

The language of the classical concept of wisdom is present by Sade in an unreasonable way. What it reveals is the modification of the relation of desire and self-knowledge by organizing the communication with others in impossible, unreasonable, ways, always conflicting with the institutionalization of roles and expectations, disagreeing from the institutionalization of nature.

Apparently, sadism would be a communicative pathology placed in the core of a promise of wisdom and self-knowledge of the flesh. But this is itself a part of the wisdom.

Sade made clear how a great variety of experiences of the inner motions of desire conclude by clash and uneasiness, showing how consciousness can't fully grasp or canalize by voluntary efforts the motion in the flesh. The idea of motion as an almost blind force, central to Sade's system of nature according to his reading of T. Hobbes in La Nouvelle Justine, means that in the case of the flesh the symptoms of restlessness are very serious and not reducible to the psychic representations.

Even if such internal motions in extreme actions are conveniently handled by a conscious included agent, they are not in necessary agreement with the communicative conventions concerning the sexual use of body and above all they are conserved in images, in very much elaborated, artificial, images.

Thus, austerely speaking, we are facing a double restlessness concerning the relation of the inner motions with regard to subjective consciousness and of conscious agency with regard to communicative (social) conditions.

Sade's narratives and experience of life are both in the crossroad of this double restlessness. But he didn't conclude from this fecund clash a concept of a "war" between the flesh and the spirit, the "desires of the flesh" and the "desires of the spirit", as one could read generally speaking in the tradition of the Church fathers and in the Conferences of John Cassian (IV Conference), particularly ${ }^{25}$.

25 Edgar C. S. Gibson (ed.), The Conferences of John Cassien in A Select Library of Nicene and Post-Nicene Fathers of the Christian Church, New York, 1894. 
In the forms of the internal affection, or in the consciousness turned to the inner motion of desire, the subject is also captured as if its truth was identical with the uneasiness of the flesh. This is the reason why Sade learned an ethical doctrine with the example of his life, but never told moral lessons ${ }^{26}$.

In the flesh the subject ciphers the difference between internal energy, self-consciousness and communication. Thus, the body as flesh represents this difference as non-coincidence, which entails multilinearity. Noncoincidence and the multilinear time move the body and move consequently the desire across the body. The ciphered difference as such is not at the hand for a thematic conscience of the body; it simply moves the body as cause of inner motion.

The essential concern of Sade's wisdom, his imperative, lies here: try to capture the cipher of the flesh being lucid with regard to its motions!

This also makes more understandable the reason for Sade's constant hyperesthesia and the binding connection between the "pleasure in transgression" and hyperesthesia.

A consciousness not commanded by communicative expectations with regard to the truth of the flesh is a partial, but important, formula for the sadic rule regarding the self-knowledge of the subject.

But, on the other side, communicative expectations are also a positive component of the sadic commitment, in the sense that interdictions are separation barriers preventing some motions. Such barriers represent the negation of motion or obstruction of motion as Hobbes before Sade told.

Referring obliquely to the constraints of hyperesthesia, in La Nouvelle Justine Sade asserts a series of thesis relating to nervous transmission and the formation of sensation ${ }^{27}$ in a theoretical construction one can apprehend as an effort to conceive what is psycho-physical causality.

Nerves responsible for sensations spread from the brain to the extremities of the body and move the "animal spirits" that are responsible for the transmission of pleasure and pain. Along nervous transmission there is always a combination of the "physique" with the "morale".

Nerves organize the mediation of the "physique" with the "morale" by establishing some connotations in the final sensation regarding the

${ }^{26}$ L' abus des meilleurs choses peut devenir dangereux: mais ici l'abus même est un bien, et plus un homme sage mettra mes systèmes en pratique, plus je lui garantis le bonheur, parce que le bonheur n'est que dans ce qui agite, et qu'il n'y a que le crime qui agite: la vertu, qui n'est qu'un état d'inaction et de repos, ne peut jamais conduire au bonheur (Sade, La Nouvelle Justine, 2 vols., Paris, 1978, vol. 1, chap. X, p. 366).

27 Sade, La Nouvelle Justine, 2 vols., op. cit., vol. 2, pp. 109-110, note. 
symbols of punishments or rewards connected to the respective actions or exterior stimulations. The difference of pleasure and pain is never a physical distinction but refers always to moral conceptions regarding punishment and reward. In La Nouvelle Justine this idea of a special moral content related to sensation is the reason for the introduction of the category of "sensation morale" 28.

With the concept of "moral sensation" what Sade is saying is that the self-awareness of the subject relating to emotional internal states is itself a combination, a synthesis of "le morale" and "le physique". Thus, physical, external movement touching the sensorial organs is reorganized by appreciations and judgments ruling "la sensation morale". This one can obstruct, accelerate or turn off the motions.

One should conclude that there is no internal self-awareness regarding pleasure or pain separately from prejudices, education, moral judgments, moral habits, social interdictions, etc. All these aspects are structured by communication and communicative connections of meaning, but have a strong influence in the movement of the "animal spirits" and in the formation of the final emotions. The synthetic self-awareness of the subject as an entire living "organization" depends on this influence. Thus, according to Sade, inner motion is never an exclusive physiological variable.

Concerning the sexual life one must acknowledge that the physical pain or the physical pleasure, and their variable intensities, are both traversed by the communicative filters of conformity or transgression, organizing cross-references. This last distinction is installed in the inner sensation and motivates differences on speed and regarding the direction of the psychic carriers of emotions.

The expansion of the individual psychic capacity to feel a variety of experiences depends on the degree of the psychic incorporation of the moral prejudices. From a liberation regarding the moral pressure of the prejudices one can expect also liberation in the capacity to feel. However, this relative degree of the reciprocal influence of the "physical" and the "moral" is always different in the individual constitution of human beings. This uniqueness makes psychic individuation possible.

What Sade and his contemporaries called the "organization"29 (l'organisation) means a mechanism responsible for the regulation of inner motions. But in the case of Sade in the living "organization" the rules are always in balanced contact with the episodic organization of psychic time.

\footnotetext{
${ }^{28}$ Idem, Ibidem, p. 110, note.

29 The term is present by G.-L. Buffon, P.-L. de Maupertuis ("Essai sur la formation des corps organisés"), de La Mettrie ("L' Homme Machine"), Charles Bonnet
} 
The fact that in the psychic causality one should always refer to a balance between the "physique" and the "morale" is a sufficient evidence to demonstrate that the so-called primeval nature of sexual activity (the reproduction of the human species) is frequently a quotation in a moral book regarding a probably tardy natural species on earth.

\subsection{The sovereign as libertine lord}

Continuing in the same interpretative line of G. Bataille's sovereignty concept $^{30}$ and keeping important results of Klossowki's brilliant analysis $^{31}$, in the essay "La Raison de Sade" M. Blanchot ${ }^{32}$ brings new light on Sade's concept of erotic sovereignty. Quoting Sade's ideal of the independence of the libertine, that means the autonomy of the subject experiencing the possibilities and limits of its own sensitive nature, $\mathrm{M}$. Blanchot reveals how Sade reproduces and renews the stoic love of necessity in the maxim "J'aime tout, je m'amuse de tout, je veux réunir tous les genres" or "le veritable libertine aime jusqu' aux reproches que lui méritent ses exécrables procédés" ${ }^{3}$.

("Considérations sur les Corps Organisés") and among the French Encyclopaedists, before its popularisation in the second half of the XVIII century. The term "organization" was used in the XIX century to express the link between "le morale"and "le physique" in the Human Being. See. P. J. G. Cabanis, Rapports du physique et du moral de l'homme, Paris, 1843; Maine de Biran, "Nouvelles Considérations sur les Rapports du Physique et du Moral de 1' Homme" in Euvres, vol. IX, Paris, 1990, pp. 1-86. Also in the XIX century one can observe other semantic instances of the same concept giving meaning to the relation between parts and whole, in the human body, and in the field of zoological taxonomy. See. P.-A.Béclard, Élemens d'anatomie générale ou Description de tous les genres d'organes qui composent le corps humain, Paris, 1827; H.-M. Ducrotay de Blainville, Sur les principes de la zooclassie, ou de la Classification des animaux, Paris, 1847. Along the philosophic dissertations in La Nouvelle Justine Sade used «l' organisation» to refer the human internal proportions responsible for the generation of desire, sensation and imagination.

30 See G. Bataille, - «La Part Maudite. Essai d'Économie Générale III (La Souveraineté)» in Idem, Euvres Complètes, vol. VIII, Paris, 1976.

${ }^{31}$ See P. Klossowski, Sade mon prochain, précedé de 'Le Philosophe Scélérat ${ }^{a}$ Paris, 1947 (reed. 2002).

32 M. Blanchot, "La Raison de Sade" (1963) in Idem, Sade et Restif de la Bretonne, Paris, 1986, pp. 9-66.

${ }^{33}$ Et c'est pourquoi Sade, dans les 120 Journées, s'est attelé à la tache gigantesque de faire le dénombrement complet de toutes les anomalies, de tous les écarts, de toutes les possibilités humaines. Il lui faut tout éprouver pour n'être à la merci de rien (Idem, Ibidem, p. 30). 
Thus, erotic sovereignty means a mental appropriation of the restlessness of motion as the unique destiny to which we are indebt. Thought (and thinking turned to episodes) is the very prison where the libertine lord has its chains and his truth.

On the other side, the idea of libertinage as an exercise of an empirical power over the others is self-contradictory, because it entails the reduction of the others to a complete absence of will. But the libertine lord needs the willingness of his victims.

The sadic lord doesn't demand the complete destruction of the other, or its complete submission, but a certain degree of non-compliance and resistance is needed, because sovereign power is power over a willing creature. In this sense the sovereign power is power over the alien will, but demanding also a response of this will.

The libertine lord searches willing victims, not inanimate things or corpses, victims he abducts from everyday life and seduces.

It is also true that a degree of non-compliance is needed on the side of the willing others. But this aspect serves to confirm that the lord is facing the power of other will.

Sade's egalitarian tendency belongs to this beauty of the noncompliance of all the others towards the lord's demand. This aspect justifies why the sadic desire is compatible with the revolution ${ }^{34}$. Also crimes against property and the inversion of the established order are symptoms of a generalized opposition revealing the resistance of the others.

The sadic sovereign needs the evidence of the resistance in order to drive the will of the others by his own desire. He is also a criminal, because he doesn't obey to the existing ruling, or to the present "state of affairs", or to the injunctions of the revolutionary strategy, but he obeys only to his own inner voice, which crudely commands the pleasure in transgression.

This aspect of the sadic ideal, I mean the pleasure in transgression, was studied by G. Bataille in detail ${ }^{35}$.

We said that the sadic sovereign must be immune to evil, because evil must be a part of eternal motion, physical and moral causality. Being immune to the power of law, even if imprisoned, it is not sufficient. Perfect sovereignty demands also immunity to evil coming from others.

\footnotetext{
${ }^{34}$ See a brief examination of the subject of terror in Marcel Hénaff and Lawrence R. Schehr, "Naked Terror: Political Violence, Libertine Violence" in SubStance vol. 27 $\mathrm{n}^{\circ} 2$ Issue 86: Special Issue: Reading Violence. (1998), pp. 5-32.

35 See. G. Bataille, L' Érotisme, Paris, 1957, Étude III - "Sade et l' Homme Normal", pp. 197- 218.
} 
But this can only happen if the libertine reduces the others and their powers to aspects of a self-creativity, converting the evil over himself to an act resulting from himself, which is an extreme (and ferocious) form of responsibility. The libertine lord loves his punishment as himself.

Energy is another name for this ferocious power over the effects of alien evil towards oneself.

This exigency of integration of energy in wisdom justifies the ironic appreciation Sade made of "pieté" in his account of the System of Nature as universal movement in La Philosophie dans le Boudoir.

Sade literary work embodies an ideal model for the observation of the internal motions of desire and its destinations which is independent and in a certain sense completely different from the normal depictions of so-called "perverted" practices. Some authors commenting the work and life of Sade said that he was a sort of predecessor of the modern observation of the psychiatric clinic, but operating by means of a self-observing subject.

At the opposite side of the perverted, Sade's life practice and Sade's literary imagination leads to the contrary of the phantasmal reduction of pleasure and desire fixation. According to Sade's imagination of the flesh, it is not possible to establish cyclic forms of pleasure economy as the ultimate truth of the flesh, thus creating a repetition rule for limited erotic sequences. The perverted needs his own partiality, his own blind rule for the repetition. His eroticism depends on his blindness concerning other possibilities of erotic sequences. He is monotonous, because he deals economically with his own resources.

The protective function of a certain degree of perversion in the economy of pleasure, in family life for the sake of the reproduction of the species, is not assured in the case of Sade. His work means much more a revelation of the menaces of the absence of the phantasmal domination over the psychic life than the evidence of a particular perverse preference or inclination. Therefore, Sade's work can mean a radical therapy against the constraints of fixed, crystallized perversions in psychic life. He shows that human beings are also obeying to the demands of the excess of "nature" and are not exclusively dependent on the rules of scarcity.

On one side Sadism illustrates the multiple paths of inner motion across the flesh coupled with erotic meaning, pleasure and pain carriers. But sadism disconnects this experience of the flesh from any privileged focuses. By Sade the repetition doesn't mean a cadence in the return of the perverted same, but instead means liberation from the enslavement in the same, abjuration of perversion for the sake of an embodied wisdom of the flesh as realm of still unknown possibilities.

In the case of Sade the pleasure in transgression is not displayed as a symptom of sexual perversion, a kind of love of sexual partiality. The limi- 
tations to erotic motion, such as moral limitations, taboo, ceremonial interdictions, or social rules represent also the symbolic carriers of the sadic desire of transgression, because they represent limitations, reductions, abbreviations of motion and desire and, accordingly, the real sources of perversion.

In a significant sense the effort of the sadic desire goes to the opposite path of the perverted. Sade cancels the fixation of desire in the phantasm; the perverted fixes repeatedly the deviated course of the desire within the paths exclusively open by the phantasm. The perverted mind lives in a state of subordination concerning the fascination of the objects which is the opposite of the freedom of the sadic sovereign. The imperative for the perverted comes from scarcity; for the sadic from excess.

However, sadism and perversion have something equivalent. Both refer the recursive identity of the phantasm or the fixation of limits. The perverted use of phantasmal identity refers to the meaning of the phantasm, literally, as a caged action, as if by this meaning one would designate the object of desire. In the case of the perverted the repetition of this recursive meaning makes the whole scene of the representation of the subject's desire. The perverted will need the fixation of phantasmal identity in order to set up the "primitive scene" of the accomplishment of his desire, with the correspondent psychic ambivalence.

But Sade needs perversion under a proviso. He writes again the scene where the perverted acts, introducing a sort of ironic suspension of the obsessive phantasmal identity, as if he looked for a never ending of desire lounging outside the cage where the phantasm inhabits. As a mise-enscène director Sade shows how the integrity of the subject's perverse desire is always fading out. This we owe to Sade: the combination of eroticism with irony, which makes an essential aspect of the description of eroticism in modern society.

\section{Delectatio Morosa ${ }^{36}$}

In the Holy Books seven corrupt types of behaviour were mentioned: fornication, quarrel, vainglory, gluttony, pride, lie and injustice. Ancient uses also embrace cosmological references to aerial spirits going together

${ }^{36}$ A larger research on the topic of delectatio morosa is needed, perhaps under the general rubric of eroticism and the forms of imagination. An interesting anthropological study on this subject is available in Charles Stewart, "Erotic Dreams and Nightmares from Antiquity to the Present" in The Journal of the Royal Anthropological Institute vol. $8 n^{\circ} 2$ (Jun., 2002) pp. 279-309. 
with the soul in its after death ascension. It is possible that biblical conceptions replicate some aspects of this ancient tradition ${ }^{37}$.

The fourth century monk Evagrius Ponticus ${ }^{38}$ was possibly the first to refer eight categories of impure thoughts or "malign spirits" for the purpose of moral teaching.

In the History of Church Fathers one can review interesting aspects of moral conceptions on sexual fantasy and condemnation of impure thoughts. Some of these earlier considerations led to an increasing of importance of the category of sins of thought (delectatio morosa, gaudium and desiderium), "unspoken sins" or "internal sins" after the Council of Trent in association with the discussion on the value of the institution of the confession ${ }^{39}$.

Penitential traditions such as the so-called celtic penitential ancient use referred to the old conceptions of the seven capital sins. In the Middle Ages one finds powerful images to the sins in Dante's Purgatorio.

After the penitential ritualized context the doctrines on capital sins evolved to the confessional practices.

In this new frame it is possible to appreciate an evolution tending to the subjectivation of guilt, especially accompanying and after the XVI century Reformation, producing a deviation of penitence and confession from collective rituals to the quest of the subjective meaning of own life.

Regarding the themes under personal confessional scrutiny, XVI century subjects were mostly from sexual connotation and among the Historians of the confessional practice there is agreement on the qualification of the evolution from Chaucer to Pascal and the Devotio Moderna as a progress from "hate" to "sexuality" themes.

The practices of the Spiritual Exercices of St. Ignatio Loyola are expected to conduce to the internal examination of the way of life of the believer, to contrition and conversion. The individual self became the focus of the religious interest in this epoch worried with personal virtue, authenticity and self-examination. The sexual life was an essential aspect.

${ }^{37}$ M. W. Bloomfield, "The Origin of the Concept of the Seven Cardinal Sins" in The Harvard Theological Review, vol. 34 nº 2 (Apr., 1941), pp. 121-128.

${ }^{38}$ See Henry Wace and William C. Piercy, A Dictionary of Christian Biography and Literature to the End of the Sixth Century A.D., with an Account of the Principal Sects and Heresies, London, 1911, Art. "Evagrius Ponticus, anchoret and writer".

39 John Bossy, "The Social History of Confession in the Age of Reformation" in Transactions of the Royal Historical Society 5 th Ser., vol. 25 (1975) pp. 21-38; P. Hurteau, "Catholic Moral Discourse on Male Sodomy and Masturbation in the Seventeenth and Eighteenth Centuries" in Journal of The History of Sexuality vol. 4 no 1 (Jul., 1993), pp. 1-26. 
Along the Church evolution concerning the doctrine of sins the Thomistic teaching was a systematisation and discussion of some textual materials of the patristic tradition, especially Augustine's. In this very influential teaching one can find the place for sins of sexual nature and the discussion of so-called "sins against nature".

A main Thomistic distinction refers to the sexual actions committed in accordance to nature, that means actions turned to the accomplishment of the sexual reproduction of the species with no waste of seminal fluid, and those other actions conducing to a deliberate extra-vaginal emission of semen. This last category included such practices as sodomy, bestiality, masturbation and other improper forms of sexual intercourse.

Another distinction deals with the opposition between "venial" and "mortal" sins. And from other perspective it is also possible to formulate the opposition "external" vs. "internal" sins.

The so-called "internal sin" delectatio morosa was subject to a careful examination in the text of De Veritate quaestio 15 art 4 and also in the Summa Theologica, Prima Pars, Secundae Partis, Quaestio LXXIV. From his scrutiny and from his interpretation of the tradition, Thomas of Aquinas came to the concept of morose delectation concluding that: "delectatio morosa, i.e. the pleasure taken in a sinful thought or imagination even without desiring it".

An interesting distinction and re-enter of the distinction occurs in De Veritate when Thomas of Aquinas firstly divides the "pleasure that follows an external act" (fornication) from the "interior pleasure" that follows "the act of thinking" and secondly considers that in some cases this distinction is not clear, for instance when the process of thinking is closely linked to the object: (...) "But their distinction is more obscure in thoughts about sins of the flesh, because, due to the weakened condition of the concupiscible part, when there is thought of such desirable objects, there immediately follows in the concupiscible part a movement which is caused by these objects".

Delectatio morosa is a pleasure of thought, an observational game which develops itself by suspending the moral intentionality of sexual intercourse. Speaking properly, morose delectation is not sex, but observation of motions transversely the flesh and their capacity to generate emotions, an internal dynamic and desire focal points in the psychic organization of the observer ${ }^{40}$. The intensification of this kind of observational games by the erotic literature is proved and evident.

40 See Jean Knox, "Sex, Shame and the transcendent function: the function of fantasy in self-development" in Journal of Analytic Psychology 50, 2005, pp. 617-639. 
After the Reformation the expression delectatio morosa was generally used with the meaning of sexual fantasy or impure and useless imagination. This concentration in the imaginary possibilities is contemporary to the subjectivity of guilt. The epoch opens a royal way to the mental manoeuvring of enjoyment possibilities and to all kinds of as if erotic experimentations. But this leads to the self-referentiality of the observer as the source of the imaginary experimentation. The observer is, simultaneously, source and object of observation, sovereign freedom and thing.

Les 120 Journées de Sodome is a formidable example of literary miseen-scène, with amazing details, since the first pages concerning the "Regulations" founding the libertine community, but also a treatise on passions at the service of self-knowledge. Sade mise-en-scène shows the triple inscription of the inner motions of passions: in communication (the social interdict and the sadic counter-interdictions) in a mirroring consciousness of the flesh and in bodily passionate actions.

Only the cinema is able to replicate Sade's passions huge fresco. In the "Regulations", the meticulous interdictions against piety or religious sentiments among the libertines and their victims are measures to purify and disinfect from moral prejudices the work of imagination and to concentrate such work in the inner motions of the passionate flesh, exclusively.

The fictions of imagination are enclosed in the narrative structure of the different libertine stories, but in the case of Les 120 Journées Sade conceived special representatives of this fictional labour he called "the historians" (les historiennes).

This "dramatis personae" is responsible for telling life stories in the first person, thus creating stories inside the main narrative and referring to other people absent from the initial diegetic auditory.

The effect of this fiction within fiction is the stimulation of the senses and inner motions of the libertine auditory by a detailed effect of screening. By narrating their own experience of excess, vice and passions, the "historians" are incentives and efficient semiotic tools for "delectatio morosa".

The integrity of Sade's model of self-knowledge based on his idea of wisdom of the flesh and erotic sovereignty depends on a radical refusal of confession. The very notions of sin, admission and repentance are contrary to the psychic energy needed to disclose the sources of desire and inner motions and contrary to its actual employment.

A complete analysis concerning libertinage and confession as models of self-knowledge still waits to be written, but it is undoubted that we are facing here divergent schemes of coordination of self-narration and selfknowledge. 
Sade's use of literary techniques conducing to delectatio morosa expresses a concern with the function of erotic consciousness which shall be at the service of enjoyment. The absence of moral blame is a requirement. But some historical conditions for the normal development of this consciousness of the independence of enjoyment must be created.

J. P. Dubost in his work on the libertine textuality ${ }^{41}$ identified on the basis of Sade's "oeuvre" and libertine literature a semiotic construction he called "theatre of desire" which develops itself around two major semiotic chains: showing and telling. The operation of these two semiotic chains is very clearly illustrated in the case of Les 120 Journées de Sodome.

This "theatre of desire" is the main achievement of the literary form in the schematisation of the reality of the inner motions in order to make possible a particular form of experimentation.

The exhortative role of the literary language leads the reader to those textual meanings that make possible a personal, interior, experience of what is showed and told. This spiritual intimacy with oneself is the promise of libertine literature and libertine wisdom leading also to the equivalent of G. Bataille's idea of "expérience intérieur".

Delectatio morosa was the classical, also pejorative name for the achievement of such proximity towards oneself.

With the libertine model of self-narration and self-knowledge modern society separates desire from guilt. By Sade this separation occurs in a paroxystic mood, miming the core identity established in the frame of the confessional mentality between bad desire, moral guilt and crime and inverting it by forging the ideal of the libertine crimes.

The semantic of eroticism of modern society went further and released all forms of consented adult eroticism from crime and also, consequently, liberated it from the general form of the libertine transgression.

\section{Concluding Remarks}

With this presentation I suggested a main thesis: what one called "sadism" is a semantic aspect in the historical evolution of the large semantic spectrum of "perversion". The modern History of the term "perversion" is articulated with a definite number of binary oppositions

${ }^{41}$ Jean-Pierre Dubost, "Libertinage and Rationality: From the "Will to Knowledge" to Libertine Textuality" in Yale French Studies, No. 94, Libertinage and Modernity (1998), pp. 52-78.

pp. $427-460$

Revista Filosófica de Coimbra $-n^{\circ} 34$ (2008) 
such as "natural" vs. "unnatural" in order to establish a link between moral judgements and a naturalistic observation of human behaviour (between morals and modern science).

Examining the notions of inner motion and flesh I concluded that Sade's work includes a serious confrontation with the classical ideal of wisdom, but such confrontation leads to an appreciation of his work that entails effects completely different from the semantic spectrum of the modern "perversion" concept.

Instead of reducing Sade's writing to a chapter in a surpassed History of "perversion" one should recognize its importance in the modern History of self-knowledge of the subject.

This will lead to a new understanding of the libertine literature and of its contribution to the emergence along two centuries of an increasing interest in the bodily and sexual modulation of the consciousness and communication.

Finally, I argue that modern society produced self-referential domains in the fields I identified under "nature", "consciousness" and "communication", thus creating coordination problems between the three spheres. A productive void resulted from the autonomy of these three areas and for its transient fulfilment a special semantic took place, as the semantic of the self-referential subjective individuality. Literature, libertine literature and Sade's "theatre of desire", more in particular, outlined conditions for meaning communication that personifies individuality from the side of the writer towards individuality on the side of the reader, referring sexual self-knowledge as an ideal and delectatio morosa as an imaginative technique.

\section{GENERAL BIBLIOGRAPHICAL REFERENCES}

P. A. ALLETZ, L'art d'instruire et de toucher les âmes dans le tribunal de la pénitence. Ouvrage utile aux prêtres qui commencent à exercer le ministère de la confession; et à tous les fideles, pour tirer de dignes fruits de ce devoir de religion, 2 vols., Paris, 1743.

P. AULAGNIER-SPAIRANI / J. CLAVREUL, / F. PERRIER / G. ROSOLATO /J.-P. VALABREGA, Le Désir et la Perversion, Paris, 1967.

ROBERT B. BAKER / KATHLEEN J. WININGER / FREDERICK A. ELLISTON (ed.), Philosophy and Sex, New York, 1998.

R. BARTHES, Sade, Fourier, Loyola, Paris, 1980

G. BATAILlE, La Part Maudite. Essai d'Économie Générale. La Consumation, Paris, Minuit, 1949. 
Idem, La Littérature et le Mal, Paris, 1957.

Idem, «La Part Maudite. Essai d'Économie Générale II (Histoire de l'Érotisme)» in Idem, Euvres Complètes, vol. VIII, Paris, 1976.

Idem, «La Part Maudite. Essai d'Économie Générale III (La Souveraineté)» in Idem, Euvres Complètes, vol. VIII, op. cit.

Idem, L Érotisme, Paris, Minuit, 1957.

Idem, « La joie devant la Mort» in D. Hollier (ed.), Le Collège de Sociologie 1937-1939, Paris, 1979, op. cit., pp. 729-745.

GEORGES BENREKASSA / SOPHIE ASLANIDES, "Libertinage and Figurations of Desire: The Legend of a Century" in Yale French Studies, N. ${ }^{\circ}$ 94, Libertinage and Modernity. (1998), pp. 29-51.

JOSEPH J. BEREST, "Report on a Case of Sadism, in The Journal of Sex Research, Vol. 6, n. ${ }^{\circ}$ 3. (Aug., 1970), pp. 210-219.

M. BLANCHOT, Sade et Restif de la Bretonne, Paris, 1986.

I. BLOCH, Marquis de Sade: His Life and Work (1899) (transl.), The Minerva Group Inc., 2002.

M. W. BLOOMFIELD, "The origin of the concept of the seven cardinal sins" in The Harvard Theological Review vol. 34 n. 2 (April 1941) pp. 121-128.

JOHN BOSSY, "The Social History of Confession in the Age of the Reformation" in Transactions of the Royal Historical Society, 5th Ser., Vol. 25. (1975), pp. 21-38.

ANNIE LE BRUN / JEAN-JACQUES PAUVERT, Oeuvres complètes du Marquis de Sade, Paris, 1986.

G. CANGUILHEM, "Qu'est-ce que la Psychologie” in Revue de Métaphysique et de Morale, n. ${ }^{\circ} 11958$.

J. COLOMBIER, Instruction sur la manière de gouverner les insensés, et de travailler à leur guérison dans les asyles qui leur sont destines, Reprod. from the edition: Paris, l'Imprimerie Royale, 1785.

J.-M. CHARCOT/V. MAGNAN, Inversion du Sens Génital et autres perversions sexuelles, Paris, 1883 (reed., Paris, 1987).

F. CHARLES-ROBERT, Les Libertins érudits en France au XVIIe. Siècle, Paris, 1998.

CATHERINE CUSSET / PHILIPPE SOLLERS / ROGER CELESTIN, "What is Libertinage?" in Yale French Studies, n. ${ }^{\circ}$ 94, Libertinage and Modernity. (1998), pp. 199-212.

J. DONZELOT, La Police des Familles, Paris, 1977 (reed. 2005).

JEAN-PIERRE DUBOST, "Libertinage and Rationality: From the "Will to Knowledge" to Libertine Textuality" in Yale French Studies, n. ${ }^{\circ}$ 94, Libertinage and Modernity. (1998), pp. 52-78.

LUCIENNE FRAPPIER-MAZUR, "Sadean Libertinage and the Esthetics of Violence" in Yale French Studies, n. ${ }^{\circ}$ 94, Libertinage and Modernity. (1998), pp. 184-198. 
ROBERT GRAY, "Sex and Sexual Perversion" in The Journal of Philosophy,

Vol. 75, n.o 4. (Apr., 1978), pp. 189-199.

J. HARARI, "Sade's Discourse on Method: Rudiments for a Theory of Fantasy" in MLN, Vol. 99, N. ${ }^{\circ}$ 5, Comparative Literature. (Dec., 1984), pp. 1057-1071.

J. HARARI / H. PÉLLEGRIN, "Exogamy and Incest: De Sade's Structures of Kinship" in MLN vol $88 n .^{\circ} 6$, Comparative Literature (Dec. 1973) pp. 1212-1237.

JEAN-MICHEL HEIMONET / JOANIKO KOHCHI, "Recoil in Order to Leap Forward: Two Values of Sade in Bataille's Text" in Yale French Studies, N. ${ }^{\circ} 78$, On Bataille. (1990), pp. 227-236.

MARCEL HÉNAFF / LAWRENCE R. SCHEHR, "Naked Terror: Political Violence, Libertine Violence" in SubStance, Vol. 27, $n .^{\circ}$ 2, Issue 86: Special Issue: Reading Violence. (1998), pp. 5-32.

PIERRE HURTEAU, "Catholic Moral Discourse on Male Sodomy and Masturbation in the Seventeenth and Eighteenth Centuries" in Journal of the History of Sexuality, Vol. 4, n. ${ }^{\circ}$ 1. (Jul., 1993), pp. 1-26.

J. IRWIN, "Heterodox Religion and post-Atheism: Bataille / Klossowski / Foucault" in Minerva, an Internet Journal of Philosophy 10 (2006), pp. 215-244.

J. I. ISRAEL, Radical Enlightenment. Philosophy and the Making of Modernity 1650-1750, Oxford, 2001.

J. JANIN, Le Marquis de Sade, Paris, 1843.

P. KLOSSOWSKI, Sade mon prochain, précedé de "Le Philosophe Scélérat»Paris, 1947 (reed. 2002).

Idem, «Le marquis de Sade et le Révolution» in D. Hollier (ed.), Le Collège de Sociologie 1937-1939, Paris, 1979, op. cit., pp. 502-532.

Idem, «La Tragédie. Traduction d' «Antigone» de Kierkegaard» in D. Hollier (ed.), Le Collège de Sociologie 1937-1939, Paris, 1979, op. cit., pp. 252-291.

PIERRE KLOSSOWSKI / ALPHONSO LINGIS, "Sade, or the Philosopher-Villain" in SubStance, Vol. 15, n. ${ }^{\circ}$ 2, Issue 50. (1986), pp. 5-25.

PIERRE KLOSSOWSKI, "A Destructive Philosophy" in Yale French Studies, N.o 35, The House of Sade. (1965), pp. 61-80.

R. VON KRAFFT-EBING, Psychopathia Sexualis, 1886 (reed. München, 1997).

P. LACROIX, Curiosités de l' Histoire de France, Paris, 1858.

G. LELY, Vie du Marquis de Sade, Paris, 1965.

DR. MARCIAT, "Le Marquis de Sade et le Sadisme" in A. Lacassagne, Vacher l'éventreur et les crimes sadiques, Paris, 1899.

A. MOLL, The Sexual Life of the Child, Books Reborn, 2000.

GEORGE L. MOSSE, "Nationalism and Respectability: Normal and Abnormal Sexuality in the Nineteenth Century" in Journal of 
Contemporary History, Vol. 17, N. ${ }^{\circ}$ 2, Sexuality in History. (Apr., 1982), pp. 221-246.

T. NAGEL, "Sexual Perversion" in The Journal of Philosophy, vol. 66, n. 1 (Jan., 16 1969) pp. 5-17.

H. PASTOUREAU, "Sado-Masochism and the Philosophies of Ambivalence" in Yale French Studies n. ${ }^{\circ}$ 35, The House of Sade (1965), pp. 48-60.

JONATHAN L. PEARL, "French Catholic Demonologists and Their Enemies in the Late Sixteenth and Early Seventeenth Centuries" in Church History, Vol. 52, n. ${ }^{\circ}$ 4. (Dec., 1983), pp. 457-467.

PH. PINEL, Traité médico-philosophique sur l'aliénation mentale, ou La manie, Reprod. from the edition: chez Richard, Caille et Ravier, Paris, an IX [1801], Paris, 1809.

JOHN PHILLIPS, «"Tout dire"?: Sade and the Female Body» in South Central Review, Vol. 19, n. ${ }^{\circ}$ 4, Murdering Marianne?: Violence, Gender and Representation in French Literature and Film. (Winter, 2002 - Spring, 2003), pp. 29-43.

J. PREVOT / T. BEDOUELLE / E. WOLFF (eds.), Libertins du XVIIe. Siècle, 2 vols., Paris, 1998-2004.

JENNIFER RADDEN (ed.), The Philosophy of Psychiatry. A Companion, Oxford, 2004.

KENNETH REINHARD, "Kant with Sade, Lacan with Levinas" in MLN, Vol. 110, n. ${ }^{\circ}$, Comparative Literature Issue. (Sep., 1995), pp. 785-808.

WILLIAM RENWICK RIDDELL, "A Case of Supposed Sadism" in Journal of the American Institute of Criminal Law and Criminology, Vol. 15, n. ${ }^{\circ}$ 1. (May, 1924), pp. 32-41.

SADE, La Nouvelle Justine, 2 vols., Paris, 1978.

Idem, La Philosophie dans le Boudoir, Paris, 1972.

ALAN SOBLE, The Philosophy of Sex and Love, St. Paul, Minnesota, 1998.

CHARLES STEWART, "Erotic Dreams and Nightmares from Antiquity to the Present" in The Journal of the Royal Anthropological Institute, Vol. 8, n. ${ }^{\circ}$ 2. (Jun., 2002), pp. 279-309.

ROBERT J. STOLLER, La Perversion. Forme Érotique de la Haine, (trad.), Paris, 2000 (reed. 2007).

ALLEN S. WEISS, "A New History of the Passions" in October, Vol. 49. (Summer, 1989), pp. 102-112.

E. VACANDARD, La confession sacramentelle dans l'église primitive, Paris, 1903. 